\title{
Address Forms and Honorifics Encoding in the Fur Society
}

\author{
Dr. Abdallah Dawod Omer Jumaa \\ Assistant Professor, \\ Applied Linguistics at University of Nyala- Faculty of Education. \\ Presently working in Department of English Language and Translation, \\ The College of Science and Arts Unaiza at Al Qassim University- \\ Kingdom of Saudi Arabia.
}

\begin{abstract}
The paper of Address Forms and Honorifics Encoding in the Fur Society is a trial study from the Fur native speaker to shed light on the Fur language and urge the Fur language native speakers to brain storm and reflect on their language to open the gate way to those who are interested in the Fur researches. It is a thorough survey of the address forms and honorifics used in the Fur society. The investigation is a thorough tour in the Fur culture of practicing their social and political relationships using the address terms and honorifics. This is depicted from the familial address forms and honorifics to embrace pre-greeting forms, system of personal names, lexical address forms, honorifics and address terms stem from marital relationships and using the personal pronoun as an address term besides the form hayi to the titles given after professions. Furthermore, the paper explains the titles and honorifics given to the rankings of ruling class and their fillers besides titles given to those who were achieving certain functions in the Sultanate.
\end{abstract}

Key words: the Fur; the Fur language; address forms; honorifics; the Sultanate

\section{INTRODUCTION}

As any African society, the Fur society accepts social hierarchy and precedence. The Fur social structure begins with Kowe itti borang, Kowe itti, Kowe taka, Kowe appa, Juredungo, Duo appa, and duobain / yatoy /abo. Beaton (1948:8) has written on the Fur social structure during the era of Sultanate - extended from the border of Tchad in the west to the north of now existing Umdurman in the east, when the Fur were solely dominating Dar fur ( Now a days is Western, Central, Southern, Eastern and Northern Darfur). The region administratively has met four Magdumates (estates) each Magdumate has been divided into Shartayships. Under any Shartayship there are many Dimligias each under a sub chief called Dilmong - the chief who holds office. Under the chief came the fief, steward or Sagal. The class stratification of the Fur, show The Sultan- Aba Kure; Sultan's Viceroy; Magdum; Shartay; Dilmong; Dimlige; Sagal; Eleng tabu; Keyang tabu/Yaangang tabu; Jurengang tabu/ Kaneng tabu; Daarang tabu, andTongingseed/ Tonging yaa.

The Fur society witnessed levels of judiciary but not like the judicial system with the judiciary distinct from the executive for the Magdums of the older sultanate had the powers of life and death while the chiefs could deal with other cases. The last sultan Ali Dinar had reserved the death penalty for himself and weakened his viceroys' powers. The Magdumates and Shartayships had their own royal courts with sub- courts. Most courts adopted the Shariyaa law in and out of Alfasher. 
And the Fur youth have their own organization with tough regulations that govern all their known activities such as hunting, harvesting, participating in the social festivals and activities etc.

The average Fur family, who lives in a small village near a valley, has very strict daily routine activities which vary according to the time of year in the autumn- -the rainy season; in the summer and in the winter.

According to Beaton (1948:10), the Fur social structure had two characteristics: the first was the evidence from the description of the patronages that shows the social scene - the holy men were given their revenue, producing estates. The second was a patent from a study of the families of the chiefs, sub chiefs, and village sheikhs of today.

The Fur call themselves Fooraa with Foordungo as a singular form. The neighbouring tribes name the Fur differently e.g., Arabs call them furaawy; Masalit call the Fur Forta with For as singular. The Sinnyar use the same singular with Masalit but with Forsi as the plural. Zagawa call the Fur koraa. The Fur have a tongue called Bele Foor (The Fur language). It is distinct from the neighbouring languages. It contains vowels and consonants typical to Equatorial languages. It is very rich in vocabulary and highly complex in its syntactic systems.

Using their own tongue, the Fur coin various address terms and honorifics in a variety of the above contexts for showing social relationships. These address terms and honorifics may or may not be similar to the other address systems.

\section{The statement of the problem}

It is noticed that the Fur language began to lose its ground among the new generations of the native speakers in the Fur society.

\section{Objectives of the Study}

In order to carry out this study the researcher stated the following objectives:

1- To acquaint the contextual usage of address terms and honorifics in the Fur society.

2- To discover if there are some differences in using the address forms and honorifics for gender in the Fur.

3- To diagnose the various address terms and honorifics used in the Fur society.

\section{THE WORLD CONCEPT OF ADDRESS FORMS AND HONORIFICS}

Focusing on social structures than focusing on the geographical arenas, nearly all the sociolinguistic systems used in all natural languages provide some means of respect or disrespect.

Various definitions are given to the terms of address and honorifics. Esame'li, (2011:183), simply defines terms of address as "words and phrases used for addressing." Then he adds that "different definitions are given by researchers" for the term.

Drawing attention to Braun's definition of address system, Al harbi (2015:12) assures that this definition includes all the available terms of addressing in a specific language. Braun in Sabova, Marketa et al. (2010:19), claims that address is a speaker's reference to his collocutor. Furthermore, he states that the system of address includes the totality of available forms and their relationships in one language. A distinction is made by Braun between bound and syntactically free forms of address. That the bound forms are integrated parts of sentences as in: Do you like staying here? The pronoun you is abound form of address. But in the sentence: 
Do you like going out, Mr. John? The noun phrase $M r$. John is considered as a free form of address, because it stands outside the sentence.

Basing on communicative competence, Lupapula and Sommer (2012:267), confirm that the available forms - mentioned by Braun - may be employed between other things in greeting encounters including opening sequences as observed for various African languages when using conversational routines that may include or exclude of kinship terms and personal names in verbal exchanges.

Lupapula and Sommer (2012: 267) add that the verbal and non- verbal greeting features besides the linguistic means of opening interaction or establishing first contact is essential to define the term address. But they agree with Braun that the broader definition of terms like discourse convention and address will thus include linguistic forms as well as aspects of their culturally adequate usage. Further, they agree that address systems as covering the totality of the available forms and their interrelations in one language.

Elaborating on the morpho- grammatical aspect, Sabova, Marketa et al. (2010:20 -21) emphasize that it concerns the forms of address in the linguistic repertoires of most world languages and it belongs to three categories of parts of speech, nouns, pronouns and adjectives respectively. Moreover, they note that the category of nominal forms of address embraces diverse types such as names, kinship terms, titles, occupational terms, terms for some types of relationships, terms endearment etc.

In his study of Address forms and Variation among University Students in Ghana, Afull (2007:185) divides names into primary names - first names or the real names, secondary names - last names, descriptive names- not the real names and titles. Titles are classified as western oriented or academic oriented; non -western oriented or spontaneous oriented.

Like address forms, honorifics received great attention and definitions.

Keating and Durant(2006:145-154) , elaborate that there are particular linguistic forms called by linguists honorifics, received a great attention from both linguists and anthropologists as a result of providing evidence about how people jointly negotiate a system of shared understandings about their ranked relationships. Basing on Irvine (1992: 251), it might be hypothesized that grammatical honorifics appear where there are royal courts and in societies whose traditions accept social hierarchy and precedence. Therefore, it might be said that honorifics are a linguistic medium of demonstrating conventionalized differences in social ranks.

Honorifics are a particular set of linguistic forms used as a matter of deference in human societies. They are used to achieve and show social power and deference among people of the same society. Honorifics tell how people jointly negotiate mutual understandings between group and individual hierarchical relationships. Studying honorifics lead to know the social stratification construction which implemented in every interaction. They help elicitation, informal designing questionnaires and observations. Honorifics as linguistic forms aid understanding relationships between linguistic forms and their social functions.

Wikipedia - the free Encyclopedia (2018) views honorifics as:

Titles that convey esteem or respect for position or rank when used in addressing or referring to a person.

An honorific is used a more specific sense to refer to 
an honorary academic title. It is also conflated with

systems of honorific speech in linguistic speech.

Agha (1994: pp.277-2778), elaborates that honorification relationships involve social status , respect or deference between communicative interactants. Because of the occurrence of honorific phenomena is the existence of intersubjectivity it shares codes of behaviour available to interactants. Honorific phenomena are viewed by Agha as of several types as:

1-Honorific pronouns 2-terms of address 3-politeness in language use 4- honorific registers.

Though Levinson and Brown in Alni'ami (2007: 1-2) , consider honorifics derived from outputs of politeness strategies where the directly or indirectly convey a status deferential between speaker and addressee or referent, Richard et al., think honorifics as politeness formulas in a particular language which may be specific affixes, words, or sentence structure. But Irvine demonstrates that linguistic honorifics are forms of speech that signal social deference through conventionalized understandings of some aspects of the form- meaning relationship.

Matti ( 2011: P. 111- 112), Reports that the phenomenon of honorifics is broadly spread in world's languages in various forms than once supposed. He adds that linguistic honorifics as conventionalized forms used by the interlocutors in a community to indicate social deference. Brown and Levinson in Matti (2011: 112), state three main types of honorifics depending on axes upon which the systems are built:1- the speaker - addressee axis; 2- the speaker reference axis; and 3- the speaker -by stander axis. Takekuro (2005: 2- 3) demonstrates that traditionally, honorifics are "considered deictic forms of speech that signal social deference through conventional understandings of some aspects of the form - relationship.

Honorifics incorporate expressions into a language's grammatical rules." Further, Takekuro explains that languages which lack grammatical honorific systems may still have honorific titles, and terms of address like personal pronouns and verb forms marking persons. Moreover, he comments on that the term honorifics is applied to a special set of lexical items or morphological affixes, pronouns, address terms, verbal endings and speech levels. Lyons (2002: 318 - 9), explains honorifics as familiar and polite pronouns regardless whether the language people use the $\mathrm{T} / \mathrm{V}$ system. Additionally, he addresses the concepts of power and solidarity besides the reciprocal and non-reciprocal T/V usage. Atena (2013:29), comment $s$ that Brown and Gilman believe that there are many bases of power such as physical strength, wealth, age, sex, the institutionalized role in the church, the state, the army and the family.

\section{SYSTEM OF NAMING USED BY THE FUR AS ADDRESS FORM}

The choice for the speaker in the Fur society, who uses address forms and honorifics to practice social relationships, varies from using names, pronouns, pre- greeting forms, titles and honorifics as depicted below:

Table (7-1): Demonstrates the Fur system of naming as address terms:

\begin{tabular}{|l|c|c|c|c|}
\hline \multicolumn{1}{|c|}{ The Real Names } & $\begin{array}{c}\text { Omen } \\
\text { Names }\end{array}$ & Surnames & $\begin{array}{c}\text { Diminutive } \\
\text { Names }\end{array}$ & $\begin{array}{c}\text { Names after days' } \\
\text { names }\end{array}$ \\
\hline Adam;Ali;Hassan; & Tugu & Kuskus & Itti kowe & Khamees/khameesa \\
\hline Mohammed;Ishag,Esa & Bagu & Koskos & Ali kowe & Arbab/ Arbaba \\
\hline Musa,Maryam,Fatima, & Toba & Jamback & Bagukowe & Saab /Saaba \\
\hline Sadiya,Mahasen,Leila, & Sambe & Keskes & Fanekowe & Jime/-- \\
\hline Halima,Mona,khadiga & Surbe etc. & Deere kolkol & Adamkowe & -- Anena etc. \\
\hline Nadia, Salwa, Hawa & & Sirimiri & Madkowe & \\
\hline Salma, Sumeiya etc. & & Karme etc & Tugukowe etc. & \\
\hline
\end{tabular}


Table (7-1) above categorizes the system of names used as address terms in the Fur society. A born child in the Fur society is given - kitabing kona- name of the Holly Quoran. This is the primary name it is usually given to the child after aging seven days. He / she will be taken out in the open air for rituals called adenga.

Because Fur language is an onomatopeaic language, the child is going to have another name after one of his most or outstanding character trait called 'dogolang kona' or 'ausa' (surname). Sometimes elders of the family members may give the child an omen name such as bagu, tugu, toba etc. suffixed by - kowe (= boy) as in: Bagu kowe, tugu kowe, toba kowe etc.

In many cases, dogolang kona or ausa (surnames) are to be dominant besides the kitabing kona (names taken from the Holly Quoran). And sometimes they are the only names for the persons in the Fur society. The Fur give names to their children after the name of days such as Jime (born on Jumaa $=$ Friday),Saba $/$ sab (born on sabt $=$ Saturday)etc.

Naming is the most essential part of addressing in the Fur society. The Fur names follow the systems below:

(i)The first name (FN) system:

The first name of the Fur is usually taken from the holy Quran kitabing cona literally translated as( the name taken from the holy Quran Book).The first names are usually the primary names. For instance: Mohammed; Adam; Ali; Halima; Khadija; Salwa etc.

\section{(ii)The surname system:}

Surnames in the Fur society, are the secondary names. They are of two categories: $1 /$ Ausa, these are descriptive names usually given to the person according to this /her dominant character trait.

2/Omen names, these are given by the elders to the children as a matter of foretelling children's bright future. For example, the names Bagu (= to be generous to the clan); Tugu (= to be the focal centre of the clan) and Toba (= to be the supporter of the clan).

(iii)Diminutive or endearment names: they are always suffixed by kowe (= child) as seen in: Adamkowe; Miyekowe; Saabakowe; Alikowe etc.

(iv)Lexical names, play a noticeable role in the Fur society besides the other names. For instance, names like, kowe / kowe itti (= a little child); kowe dey(= a boy), kowe niew (= agirl); duo (a man), duo appaa (= a big man), duo dey (= male person), duo bain (= an oldman); ya (=a woman), yangkowe (= a young woman), allangkoyi (= a woman), yatoyi/ abo (= an old man) are all considered among others lexical names. Sometimes they can be followed by the primary names noted above such as in duobain Adam, yatoye Digire, kowe itti Ali etc. Both names and lexical names are used in the Fur society to meet the addressing purposes.

\section{Personal Pronoun as address Term}

(i)The Personal pronoun

The personal pronoun's role is so great in using for addressing purposes in the Fur society.

It was noted before that it is used in the pre- greeting address formulae. The first person singular pronoun ka is used to address one's self (monologue) e.g., KaToba (= Iam Toba / Me Toba) and the plural form ke has the same usage as in ke kuwaa keya(= We men). The $2^{\text {nd }}$ person singular plural prounouns are used to address people present as illustrated in : Je Maadkuwe (= you Maad kuwe) and Be dogola/dola(= you children). The third person singular 
form ye and the plural form yeeng are used to address the people who are absent. For example, Ye alimeyi. (= She is Alime.) and Yeeng yangage. (= They are women.)

Table (7-2): Shows the Fur personal pronouns used as address terms

\begin{tabular}{|c|c|}
\hline $\begin{array}{l}\text { First person: } \\
\text { Singular Ka / kə / = I } \\
\text { Plural Ke / ke / = we }\end{array}$ & $\begin{array}{l}\text { Ka nung aam .(= I eat porridge.) } \\
\text { Ke noong kaam.( = We eat porridge.) }\end{array}$ \\
\hline \multirow{5}{*}{$\begin{array}{l}\text { 2rd person : } \\
\text { Singular: Je /dge / = you }\end{array}$} & Je duo/allang koyi (= you man / woman). \\
\hline & Je kowe (= you child both male and famle). \\
\hline & Je duongya (= you woman). \\
\hline & Je Allang koye (= you woman) \\
\hline & Je Allang Abed (= you man). \\
\hline $\begin{array}{l}\text { 2nd person } \\
\text { plural: Be /be/= you pl. }\end{array}$ & $\begin{array}{l}\text { Be kin (= you plural pronoun for both male and female), } \\
\text { as in: Be kin yanga / kuwa .(Translated as: You women / } \\
\text { people.) }\end{array}$ \\
\hline \multirow{5}{*}{$\begin{array}{l}\text { 3rd person: } \\
\text { Singular: Ye } / \mathrm{je} /=\text { he } \\
\text { Plural: Yeeng } / \mathrm{j} 3^{\mathrm{y}} /=\text { they }\end{array}$} & ye kuwa / kulding (= you people for both male/female). \\
\hline & yeeng aala ge. (They are kins pl. for both male/female). \\
\hline & yeeng kuwa keya ge.(They are you men.) \\
\hline & yeeng dogola /dola ge.(They are boys /girls.) \\
\hline & yeeng kane kinna (They are girls.) \\
\hline
\end{tabular}

The Table (7-2) exhibited the Fur personal pronouns used as address forms include:

(ii)First Person Pronoun

Ka 1st person singular pronoun used for speaker's identification as in Ka Adam (= Iam Adam).

$K e$ 1st person plural pronoun identifies group speaker's as in: ke kuwa keya (=We men).

(iii)Second person Pronoun

Je 2nd person singular pronoun used to address a person present e.g. Je Ali (= you Ali).

Be 2nd person plural used to address a group of people present as in Be kin kwa $(=$ You people).

\section{(iv)Third Person Pronoun}

Ye 3rd person singular used for the person who is absent e.g. ye kowe kal ela (= the boy who is absent should come.)

Yeeng 3rd person plural used for a group that is absent e.g. yeeng kal kelal $(=$ the absent persons should come.)

The attention should be drawn to that, the Fur third person singular pronoun is used with all persons, gender, and umber to express summons as in table (2-3), below that depicts the Fur Personal pronouns.

\section{The word Hayi Used as Address Term for All Persons}

Table (7-3) The Fur address form 'Hayi',(Used with all persons)

\begin{tabular}{|l|l|l|}
\hline e.g & Hayi & In duo/allangkoye/kowe etc. \\
\hline & Hayi & King kuwa/yaanga/doola etc. \\
\hline & Hayi & Je in duo/kowe/allaang kuye etc. \\
\hline & Hayi & Kuldinga. \\
\hline
\end{tabular}




\section{AS REFLECTED BY THE TABLE (7-3),THE WORD HAYI USED AS ADDRESS TERM FOR ALL PERSONS / GENDER AND NUMBER.}

\section{The Pre- greeting Formulas Address Terms}

Like the Bantu languages of East Africa, the Fur open their social interactions by using the pregreeting address forms with rising pitch as in; Baing la? (= Are you present?; Bela la? (= Have you come? ; Bago la? (= Have you arrived?). All the address forms prefixed by B- prefix are used for addressing a female or male group of people. The prefix B- will be changed into J- prefix to say Jaingla? ; Jela la? And Jagola? For addressing 2nd person singular male or female. The answer for all pre - greeting address forms (questions) is ey um ey um formula.

Table (7-4): Shows the Pre-greeting Address terms

\begin{tabular}{|l|l|}
\hline Baing la? & Are you present?(Used for plural) \\
\hline Belala? & Have you arrived? (Used for plural) \\
\hline Bagola? & Have arrived? (Used for plural) \\
\hline Jago la /Jela la /Jaing la? & Have you arrived/come/present? (Used for singular) \\
\hline Tabung Jago. & Come ahead.(Used for singular) \\
\hline Tabung Bago. & Come ahead?(Used for plural) \\
\hline
\end{tabular}

Sometimes the pre- greeting formulae follow the pronoun ye (= you used for both singular and plural) + noun. Examine the following examples:

(4)Ye Kuwaa baingla? (= Are you people/ brothers present?)

(5)Ye Aala bela la? (= Have you my kins /folk arrived?)

(6)Ye dogola/dola bago la? (= Have you children arrived?)

In all the sentences above, the (ye + plural noun + pre- greeting formula) construction is noticed. The same structure is illustrated below but with singular noun replaces the plural noun in the sentences:

(7)Ye duo jago la?(= Have you arrived man?)

(8)Ye kowe jela la? (= Have you come child?)

(8) Ye Bagu jaing la?(= Are you present Bagu?

Table (7-5): Demonstrates the pre-greeting Address terms preceded by the pronoun ye ( $=$ you used for all persons) Or nouns

\begin{tabular}{|l|l|}
\hline Ye kuwa baing la & Are you present? (Used for both males and females) \\
\hline Ye kuwa bago la & Have you arrived? (Used for both males and females) \\
\hline Ye kuwa bela la? & Have you arrived? (Used for both males and females) \\
\hline Ye duo jaing la? & Are you present? (Used for both males and females) \\
\hline Ye duo jago la? & Have you arrived? (Used for both males and females) \\
\hline Ye duo jela la? & Have you arrived? (Used for both males and females) \\
\hline
\end{tabular}

The pre-greeting forms can be preceded by personal names as in:

(1)Adam jago la? (Have you arrived?)

(2)Tugo jaing la? (= Are you present Tugu?)

(3)Nyutu jela la?(= Have you come Nyutu?)Etc.

Adam; Tugo and Nyutu are names.

Table (7-6):Explains the pre- greeting Address terms preceded by nouns

\begin{tabular}{|l|l|}
\hline -Kuldinga baing la/ bago la / bela la? & Have you arrived people? \\
\hline - Aala / baing la / bago la / bela la? & Have you arrived my kins? \\
\hline
\end{tabular}




\section{Lexical Address terms}

Various lexical address terms are used for persons in the Fur society. These are seen in the table (7-7) below. Some of them are taboo.

Table (7-7): Exhibits Lexical Address terms Used by the Fur

\begin{tabular}{|l|l|}
\hline kowe itti fukka & newly born baby \\
\hline kowe itti boring & a baby of milk sucker \\
\hline Kowe itti kare kome & A baby who last born \\
\hline kowe taka & a boy of 10 to 14years old \\
\hline kowe appa deye & a boy of about 15 to16 \\
\hline kowe appa niew & a girl of about 15 to16 \\
\hline kowe kureme (usually male) & a boy of nearly premature \\
\hline Ditan & a little brother/sister \\
\hline Deda & eldest sister \\
\hline Duo & Man \\
\hline duo deye / allang abid & Man \\
\hline duo nya/ allang kowii & Woman \\
\hline duo bain & old man \\
\hline Sere & $\begin{array}{l}\text { a woman who has sexual relation with another } \\
\text { man out of marriage. }\end{array}$ \\
\hline a jala & a bitch \\
\hline Farga & born illegally \\
\hline Jaal & $\begin{array}{l}\text { a man who has sexual relation with other } \\
\text { woman out of marriage. }\end{array}$ \\
\hline Mooge & responsible for governors' media affairs. \\
\hline
\end{tabular}

\section{Titles and Honorififics}

Titles and honorifics are divided into categories as family status, professions, social organization, and ruling classes as in:

(i) Titles for family status:

This category is based on age for demonstrating familial ranking of Fur society. Fathers kin from both father's father side and father's mother side will be explained as seen from the table (7-8) bellow.

Table (7-8): Depicts the honorifics for Father's kin

\begin{tabular}{|l|l|}
\hline Fathers' kin & Meaning in English \\
\hline baa & Father \\
\hline baang bara (baa itti) & Father \\
\hline baang niew (anya) & Aunt \\
\hline baang baa (wuo) & Grandfather \\
\hline baang mama (wuo) & Grandfather \\
\hline baang iya (abo) & grandmother \\
\hline baang kala (abo) & grandmother \\
\hline baang anya (abo) & grandmother \\
\hline bain & elder brother \\
\hline
\end{tabular}

We can see the honorifics given by the Fur society to father's kin. Baang baa (father's father and father's uncle) is wuo (grandfather) plural wuonga (grandfathers).Baang iya na deeng iyang iya (father's mother; father's mother's mother ); and baang anya na baang kaala (father's aunt and uncle), are called abonga (grandmothers) singular is abo(grandmother). Father's sister is anya (aunt); father's brother is baa / baa itti literally translated as father/young father. 
Mother's kin receives various honorifics too. Mother is iya her sister is kala her brother is mamaa. Mother's mother and her sister are given the honorific abo(grandmother). Wou (grandfather) is an honorific for both mother's father and his brother. Table (7-9) below demonstrates mother's kin in the Fur society.

Table (7-9): Mother's kin

\begin{tabular}{|l|l|}
\hline Mothers' kin & Meaning in English \\
\hline iya & Mother \\
\hline iyang iya (abo) & grandmother \\
\hline iyang baa (wuo) & grand father \\
\hline iyang kala (abo) & grandmother \\
\hline iyang anya (abo) & grandmother \\
\hline iyang baang bara (wuo) & Grandfather \\
\hline iyang bara deye/doon (mama) & Uncle \\
\hline iyang bara niew (kala) & Uncle \\
\hline deda & elder sister \\
\hline
\end{tabular}

There are address terms given for the extended kin of both fathers and mothers kin. Since the Fur society in most cases is polygamy society you can hear the address forms such as baang kowe deye called bara (brother) in in the Fur society, baang kowe niew (daughter) called sister. Both baang kowe deye and baang kowe niew refer to the brother and sister who are form father's wife other than your mother. The same concept is true for both iyaang kowe deye and iyaang kowe niew. In Fur, also there is the concept of baang barang kowe deye(father's brothers' son) and anyaang kowe deye (father's sister's son)besides iyaang brang kowe deye (mother's brother's son) and kalaang kowe deye (mother's sister's son) are all your brothers and their daughters are your sisters.Table (7:10)below summarizes this.

Table (7:10) Address terms for extended kin

\begin{tabular}{|l|l|}
\hline The Fur address terms for Extended ken & Meaning in English \\
\hline baang kowe (deye) (bara) & Brother \\
\hline Baang Kowe (niew) niew (bara) & Sister \\
\hline baang barang kowe deye (bara) & Brother \\
\hline baang barang kowe niew (bara) & Sister \\
\hline iyang kowe deye ( bara) & Brother \\
\hline iyang kowe niew (bara) & Sister \\
\hline iyang barang kowe deye (bara) & Brother \\
\hline iyang barang kowe niew (bara) & Sister \\
\hline niewing kowe deye/niew (dalang) & Nephew \\
\hline
\end{tabular}

Bang dola/dogola (brothers /sisters from father) iyang or Amang dola /dogola (brothers / sisters from mother), Anyang dola/dogola (father's sister's sons / daughters), kaalang dogola/ dola (mother's sister's sons/ daughters), maamang dola / dogola (mother's brother's sons/daughters) and dogolang or dolang dogola / dola(sons'/daughters's sons / daughters) always called attinenga (grandsons).

\section{(ii)Honorifics stem from Marriage Relationships}

Father- in- law has given the honorific baa means father, and mother- in- law is given the honorific iya means mother. As brother- in -law of husband's brother is kona in Fur society, wife's brother is jaru and wife's sister and husband's sister are called kora. The women who share the same husband legally are onaga singular is ona. See the table (7-11). 
Table (7-11-): Honorifics stem from marriage relationships

\begin{tabular}{|l|l|}
\hline Honorifics stem from marriage relationships & Meaning in English \\
\hline magal /ba (Father of husband/wife) & father- in -law \\
\hline mare /iya (Mother of husband/wife) & mother - in- law \\
\hline kona (brother of husband) & brother - in - law \\
\hline jaaru (brother of wife) & brother - in - law \\
\hline kora (sister of husband) & sister - in - law \\
\hline kora (sister of wife) & sister - in - law \\
\hline ona (sharing the same husband) & married the same husband \\
\hline
\end{tabular}

\section{(iii)Titles for social Organizations}

Titles of social organizations are prolifically used in the Fur society. The top of ladder is eleng tabu (the head of the village) and the bottom of the ladder is tonging ya (the house wife).

Table(7-12)Titles for Social Organizations:

\begin{tabular}{|l|l|}
\hline Title & Meaning in English \\
\hline eleng wakeel / eleng tabu & the head of a village \\
\hline daarang tabu & the head of mess (daara) \\
\hline keeyang tabu & the head of men \\
\hline yangang tabu & the head of women \\
\hline jurengang Tabu & the head of youth (males) \\
\hline kaneng tabu & the head of youth (female) \\
\hline botoring tabu & $\begin{array}{l}\text { the head of the place where the youth always go and dance } \\
\text { (botor). }\end{array}$ \\
\hline tonging seed & the male hard working house holder \\
\hline tonging ya & the female hard working house holder \\
\hline
\end{tabular}

The Fur social structure is organized as seen in the table (7-12) above: Eleng tabu/ wakeel (governor of the village), is the top of the village who controls the village by the assistance of keyaing tabu(head of men), jurengang tabu(head of male youth), yangang tabu (head of women),kaneng tabu (head of female youth), botoring tabu (a person who keeps order in dance play-ground), tonging seed(a male house holder) and tonging ya (a house wife).

\section{(iv)Titles for professions:}

Various activities in the Fur society, call for various professional names. The professional titles nominated here are just for exemplification only. The table (7:13) below shows some professional titles use as professional referents in the Fur society.

Table (7-13) below shows some of the Fur titles for professions

\begin{tabular}{|l|l|}
\hline Names after Professions & Meaning in English \\
\hline Meer & black smith \\
\hline Auladungo & hunter \\
\hline Rayidungo & farmer \\
\hline Kuodungo & herder \\
\hline Fage & teacher of Quoran \\
\hline Magir & student of Quoran \\
\hline tagina kuwa / dalima /sukena & soldiers /police \\
\hline
\end{tabular}

\section{(v)Honorifics and Tiles for Ranking of Ruling Cass}

AS a matter of respect to the ruling class members in the Fur society, it rare to call a ruling class member by his / her name. Men are referent to $b a$ or $a b a$ followed by his name. Women addressed as merama singular is meram then their names. This is in general. But ruling settings such as council of $b a$ /aba kure (Sultan) or tong kure (government and government 
departments) and courts besides the local governors' councils various honorifics and titles are used as demonstrated in table (7: 14).

Table (7- 14) : Titles and honorifics for ranking of the ruling class:

\begin{tabular}{|l|l|}
\hline Aba Kury/ Sultan & The top of the kingdom and had the power of life and death. \\
\hline Urundulu & Sultan's head \\
\hline Abu Fure / Abu Kamneh & The neck of Sultan \\
\hline Orreng Dulo & the threshold of the door \\
\hline Abu Dimang & The right hand of the Sultan \\
\hline Abu Uma & The back of the Sultan \\
\hline Magdum/ Mandub & $\begin{array}{l}\text { The police commander before the era of Sultan Ali ,Magdum had } \\
\text { the power of life and death. }\end{array}$ \\
\hline Kiso/Shartay/ Abu & The representative of Magdum in some area of the Magdumate \\
\hline Dilmong & The chief of Dimliga \\
\hline Dimlige & One of the sub governors of the shartayship. \\
\hline Sagal/ Steward & $\begin{array}{l}\text { A man of local influence always respected and revered for he } \\
\text { above all could temper the wind to the shorn lamp. }\end{array}$ \\
\hline The chief & $\begin{array}{l}\text { Magdum's channel of communication, head of the drum covering } \\
\text { festivals. }\end{array}$ \\
\hline
\end{tabular}

Aba kury or sultan: the top in the ruling class hierarchy. He is the governor of the whole sultanate. He had had the last decision.

- Magdum / Mandub: In the older sultanate the Magdum had powers of life and death and others. The title of Magdum had substituted by sultan Ali Dinar to Mandub. Mandub was police command.

- $\quad$ kiso/shartayi/Abu: various names for the same rank; the representative of magdum in one of areas in the Magdumate.

- Dilmong: the rank above dimligias(plural of dimilige). He is the chief of dimligias. Dimligia: subdivisions of shartayship governors.

- The chief: magdum's chanel of communication, Head of the drum covering festival with his contributions of the royal coffers.

- Sagal / steward: a man of local influence always respected and revered for he above all could temper the wind to the shorn lamb.

It was customary to name the chief dignitaries after various parts of the Sultani body. Therefore,The Fur administration coined the following titles:

- $\quad$ Abu dimang = Sultan's right hand.

- $\quad$ Abu uma = the dorsal vertebrae (back of the Sultan).

- $\quad$ Abu Fure or Kamneh = the Sultan's neck

- Urundulu = the head of Sultan.

- Orreng dulung (dulo): the threshold of the door.

It should be noticed that the titles Omda, Sheik or mandub are borrowed from Arabic, they are not original names in the Fur administrative system.

\section{(vi)Titles and Honorifics for Achieving Particular Activities in the Sultanate}

In the Fur Sultanate administrative system some clans and individuals carried out particular achievements for the Sultanate similar to the functions of ministries in today's estates. For instance, the job carried out by Forenga clan(ore) who were responsible for the Sultan's personal fief ( ro kury - royal estate) and Jubanga who were checking the efficient collection of the tithe dues which fell on every one of their subjects.(The activities of these two clans were similar to the job of Ministry of Finance in any estate today). Bassinga the individuals who were 
the men of importance in courts and the daalima (the police) and the Mandoub-the police commander were all carrying out the job of the interior ministry and so forth.See the table (715) below which depicts some honorifics and titles given to the clans and individuals of achieving certain activities in the Fur Sultanate administrative system.

Table (7-15): Honorifics and titles for achieving particular activities in the Sultanate.

\begin{tabular}{|l|l|}
\hline $\begin{array}{l}\text { Title and } \\
\text { Honorifics }\end{array}$ & The particular activity \\
\hline Morgenga & A clan (orre) so many rain priests are among its ranks. \\
\hline Forenga & $\begin{array}{l}\text { The title assigned to the managers of the Sultan's personal fief (ro kury- } \\
\text { royal estate). }\end{array}$ \\
\hline Kamnenga & $\begin{array}{l}\text { An Aristocratic clan (orre) includes in its ranks the family of the Shartay of } \\
\text { Dar kerne. }\end{array}$ \\
\hline Fungora & Title given for salt-rich Mountain. \\
\hline Bassinga & $\begin{array}{l}\text { Fief holders- a rank rather than a clan. They were men of importance at } \\
\text { courts. }\end{array}$ \\
\hline Jubanga & $\begin{array}{l}\text { They were the toured men of king's domains to check the efficient } \\
\text { collection of the tithe dues which fell on every one of their subjects. }\end{array}$ \\
\hline
\end{tabular}

\section{DATA ANALYSIS}

Reading the data results of the DCT questionnaire, interview and observation they nearly all agree to each as seen the tables (8-16; 8-17 and 8-18) below,

Table (8-16): The DCT Test Questionnaire Results Analyses

\begin{tabular}{|l|l|l|l|}
\hline The item & Agree & Disagree & $\%$ \\
\hline 1-pre-greeting address forms & 60 & - & 100 \\
\hline 2-the system of personal naming & 60 & - & 100 \\
\hline 3-kinship honorifics & 60 & - & 100 \\
\hline 4- lexical address forms & 60 & - & 100 \\
\hline 5-honorifics stem from marriage relationships & 60 & - & 100 \\
\hline 6- the pronoun used as address form & 60 & - & 100 \\
\hline 7- the hayi form used as address term for all persons & 60 & - & 100 \\
\hline 8- titles after the professions & 60 & - & 100 \\
\hline 9-titles and honorifics for social organizations & 60 & - & 100 \\
\hline 10- titles and honorifics for ranking of ruling class & 20 & 40 & 33 \\
\hline 11-titles for achieving particular activities in the Sultanate & 20 & 40 & 33 \\
\hline
\end{tabular}

The results of the DCT test questionnaire show that all hundred percent $(100 \%)$ of the participants agree to all items except the items of titles and honorifics for ranking of ruling class and the titles for achieving particular activities in the Sultanate.

Table (8- 17) : Results of Un structured Interview

\begin{tabular}{|c|c|c|c|}
\hline The Item & Yes & No & $\begin{array}{c}\text { Round } \\
\text { Figures }\end{array}$ \\
\hline 1-pre-greeting address forms & 60 & - & 0.1 \\
\hline 2-the system of personal naming & 60 & - & 0.1 \\
\hline 3-kinship honorifics & 60 & - & 0.1 \\
\hline 4- lexical address forms & 60 & - & 0.1 \\
\hline 5-honorifics stem from marriage relationships & 60 & - & 0.1 \\
\hline 6- the pronoun used as address form & 60 & - & 0.1 \\
\hline 7- the hayi form used as address term for all persons & 60 & - & 0.1 \\
\hline 8- titles after the professions & 60 & - & 0.1 \\
\hline 9-titles and honorifics for social organizations & 60 & - & 0.1 \\
\hline 10- titles and honorifics for ranking of ruling class & 20 & 40 & 0.2 \\
\hline 11-titles for achieving particular activities in the Sultanate & 20 & 40 & 0.2 \\
\hline
\end{tabular}


Table (8-17) shows the agreement of results of unstructured interview to the results of the questionnaire above.

Table (8-18): The Observation Results Analyses

\begin{tabular}{|l|c|c|c|}
\hline The Item & Yes & No & Ratios \\
\hline 1-pre-greeting address forms & 60 & - & 1 \\
\hline 2-the system of personal naming & 60 & - & 1 \\
\hline 3-kinship honorifics & 60 & - & 1 \\
\hline 4- lexical address forms & 60 & - & 1 \\
\hline 5-honorifics stem from marriage relationships & 60 & - & 1 \\
\hline 6- the pronoun used as address form & 60 & - & 1 \\
\hline 7- the hayi form used as address term for all persons & 60 & - & 1 \\
\hline 8- titles after the professions & 60 & - & 1 \\
\hline 9-titles and honorifics for social organizations & 60 & - & 1 \\
\hline 10- titles and honorifics for ranking of ruling class & 20 & 40 & 0.3 \\
\hline $\begin{array}{l}\text { 11-titles for achieving particular activities in the } \\
\text { Sultanate }\end{array}$ & 20 & 40 & 0.3 \\
\hline
\end{tabular}

Observation results table (7-188) agree to the results of both questionnaire and unstructured interview above.

\section{DISCUSSION}

Address terms and honorifics which are used in the Fur society, seen in the familial, social organizational, governmental councils and courts contexts.

\section{(i)Social contexts}

\section{(a)Titles for professions}

The Fur give titles after the professions practiced by the persons. These are clear in the following names:

- Aula dungo (= a hunter)

- Reyidungo (= a farmer)

- kuodugo (= a herder)

- Daalimadungo (= a soldier)

This type of titles is always suffixed by the suffix (- dungo) which changes into the plural suffix (- kuwaa), when the singular title of profession is pluralized as shown below:

- Aula kuwaa(= hunters)

- Reyi kuwaa (= farmers)

- Kuo kuwaa (= herders)

- Daalimakuwa (= soldiers)

Another type of the professional titles is lexical that its plural suffixed in ( $-a$ ) suffix, but the singular suffixed variously as depicted in:

- Faginga pl. (= teachers of the holy Quran) fagi sing.

- Sukena pl. ( = police) suken sing.

-Majira pl.(the students of the holy Quran) majir sing.

-Meera pl.(= the black smiths) meer sing.

Etc.

The third kind of the professional titles used in the Fur society is borrowed from Arabic and Furized:

$$
\begin{gathered}
\text { mudaris (= male teacher) } \\
\text { mudarisa (= female teacher) }
\end{gathered}
$$




$$
\begin{aligned}
\text { dictor } & (=\text { medical male doctor }) \\
\text { dictora (= } & \text { medical female doctor }) \\
& \text { and so forth. }
\end{aligned}
$$

\section{(b)Honorifics and Titles}

Honorifics and titles used to show deference between the members of the Fur society, vary as familial, social, and ruling- class's contexts.

\section{(i)Familial Honorifics}

In order to express deference among the family members, the Fur use age-graded honorifics and titles. These start from the top of family ladder with wuo (= grandfather or father of father/mother); baa (= father or father's brother baa itti literally translated as younger father) anya (= father's sister / aunt); bain (= male elder brother/ elder brother).These are on one hand, on the other hand, abo (= grandmother, father's/ mother's mother); iya (= mother, husband's/wife's mother); maama (= uncle, mother's brother); kaala (= mothers sister/aunt) besides, deda (= elder sister) are used.

The honorifics stem from marriage relationships are also known in the Fur society. For example, the honorifics like magal baa magal are used for the man whose daughter is married by the addresser. So far the honorifics mare /ya or iya mare are used to address wife's mother. As wife's brother is jaaru, both wife and husband's sisters are addressed as koranga ( $p l$.) and kona (sing.), though husband's brother is kona.

\section{(ii)Social Organizations' Titles and Honorifics:}

Social organizational titles and honorifics, vary from eleng tabu (= the head of the village) to daarang tabu (= the head of the mess). Eleng tabu is a man of influence in the village he has also given names such as Sheikh and eleng wakeel (borrowed from Arabic and Furized). He has consultants like keying tabu(= the head of men); jurengang tabu(= the head of male youth); yaangang tabu(= the head of women); kaneing tabu (= the head of female youth) besides eleng fage ( $=$ the teacher of the holy Quran).All the noted heads are obeyed by the members of their organizations.

The role of the social organizations is clearly reflected in the daily of an average the Fur member society who lives in his village near a valley side. He /she leads activities throughout the seasons of the year mainly farming; herding; hunting; fishing; gathering fruits and in few cases takes a counterattack, when raids take place on his own cows ; village or neighbourng village. Here are some instances the Fur social organizations' activities:

Tause (= cooperation in farming or building tonga (huts) ):This is one of the main activities of the people of the village in which the roles of is noticeable, as the women and female youth organizatioons and their leaders prepare food ; drink and water, keying tabu and jurengang tabu and their organizations go and gather the materials of building huts like daye; oora;baaranga and boota, besides building the huts cooperatively by themselves.

In the farming seasons, the social organizations lead together an allayi aun (= to be helped by Allah) . It is another type of Tause, but it takes place in one of the farming stages. For example, ploughing, seeding or harvesting the crops etc.

Subo - the seven days festival- is another field of social activity in the Fur society. a member It takes place when a member in a village marries or circumcises his/her children. Sometimes a group of boys can be circumcised on the same day and in the same place (Gargab). These make 
the Fur spend seven days' festival jaul and nyorre (dancing and singing) and eating meat and drinking.

Aulaa,(hunting), can be led individually (junkat), or in a body. When it is led in a body, jurenga (male youth/chaps) of one village with their jurengang tabu (the head of youth) will carry out this. Some times jurenga from the nearby villages can lead aula under the guidance of one jurengang tabu.

Deer (war),it is guided by a leader called ornang who is usually elected by the elders to lead the jurenga(male youth) and kuwa keya (men) in the fighting field during the war time. To be selected Ornang needs some character traits like bravery, cleverness, loyalty, patience, wisdom etc. The Fur never go for war unless the border of their Sultanate, village, town or their cows are raided. In these cases they always take counter attack to protect their borders or regain their cattle.

\section{(iii)Honorifics and Titles for Ruling Class}

Several honorifics and titles are used for the ruling class in different ruling class levels. These are depicted as follows:

The top most rank in the Fur Sultanate is Aba kure, the Sultan the owner of the Sultanate his yes is yes, and his no is no. He preserves the powers of life and death. He has the last decision. Having honorifics his ministers or assistants are Urundulu = the head of Sultan; Abu dimang = Sultan's right hand; $A b u$ uma = the dorsal vertebrae (back of the Sultan); Abu Fure or Kamneh= the Sultan's neck; Orreng dulung (dulo): the threshold of the door; Mooge is responsible for information affairs.

According to their achievements in the Sultanate some subdivisions of the ruling titles or ranks noticed for orrenga (clans) such as:

- Morgenga clan: So many rain priests are among its ranks.

- Forei (foreinga): The title assigned to the managers of the Sultan's personal fief (Ro kury-royal estate).

- Kamnenga: An Aristocratic clan includes in its ranks the family of the Shartay of Dar kerne.

- Fungoro: Title given for salt-rich Mountain.

-Bassinga: Fief holders- a rank rather than a clan. They were men of importance at courts.

- Jubanga: They were the toured men of king's domains to check the efficient collection of the tithe dues which fell on every one of their subjects.

Magdum/Mandub is the second rank in the Sultanate: In the older sultanate the Magdum had powers of life and death and others. The title of Magdum had substituted by sultan Ali Dinar to Mandub. The Mandub was a police command.

kiso/Shartayi/Abu: The third ruling class rank.Various names were given for this rank; the representative of magdum in one of areas in the Magdumate.

Dilmong: the rank above dimligias. He is the chief of dimligias.

Dimligia: subdivisions of shartayship governors.

The chief: magdum's chanel of communication, Head of the drum covering festival with his contributions of the royal coffers.

Sagal / steward: a man of local influence always respected and revered for he above all could temper the wind to the shorn lamb. 
The above honorifics and titles also can be heard in the councils and courts (in the form of councils) which were known by the Fur society. The supreme council and court was the $A b a$ kure's one in which very serious matters concern the Sultanate used to be discussed such as war declaring, judiciary, legislation. Each Magdumate has its own court which is a council chaired by the Magdum himself or by a person to be appointed by him. Any Sartayship owns its own court and sub courts which are councils headed by the Shartay/Kiso /Abu or persons to be appointed by him.

\section{CONCLUSIONS}

As the most African societies the Fur society meets a solid social organization which begins with kowe itty borang and ends with tonging yaa in which it uses different address forms to show deference between the interactants. The Fur use pre- greeting formulas to introduce greetings. The pre-greeting formulas begin with address forms in the formulas of questions followed by greeting formulas answered by the formula eyie umm. To show deference in the Fur society, using personal names, surnames, familial honorifics, professional honorifics and ruling class honorifics are noticed. It deserves mentioning that ruling class honorifics today undergo replacing by Arabic address forms and honorifics.

\section{References}

Agha, Asif(1994:277- 278). "Honorification”. Annual Review of Anthropology,Vol.23. (1994) pp.277 -302.

Al- Ni'aymi, Hashim (2007: 1 - 2). "Honorific Expressions in Arabic and English with Reference to Other Languages". Tikrit University Journal for Humanities Vol. (14)No. (3) April (2007).

Afull, Joseph B. (2007:185). "Address Forms and Variation among University Students in Ghana". Nordic Journal of African Studies 16 (2):179 - 196 (2007).

Al harbi,Tahani A. A.(215: 1 -12). A Socio-pragmatic Study of Forms of Address and Terms of Reference in Classic Arabic as Presented in the Chapter of Joseph in the Holy Quran. The University of Leeds School of Languages, Cultures and Societies (LCS) May2015.

Abdel , Lupapula and Sommer, Gabriele (2012: 266 - 277). "Comparing Address Forms and Systems: Some Examples from Bantu". Selected Proceedings of the 42 ${ }^{\text {nd }}$ Annual Conference on African Linguistics, ed. Michael R. Marlo et al., 266 - 277. Somerville, MA: Cascadilla Proceeding Project.

Attina,Mohnmoodan (2013). The Semantics and Pragmatics of Address Forms in Persian. M.A. Thesis in Linguistics . Nowegian University of Science andTechnology- Faculty of Humanities. Trodhein 2013.

Beaton, A.C. (1941:181- 187)."youth Organization Among The Fur".Sudan Notes and Records 24: 181-187

Beaton,A.C. (1942: 8-35). “The Fur”.Sudan Notes and Records.29:1-39.

Keating, Elizabeth and Duranti , Alessandro(2006:145). "Honorific Resources for Construction of Hierarchy in Samoan and Pohnpeian".The Journal of the Polynesian Society. Polynesian Society (N.Z.) 115 (2): 145 - 172. June 2006 with 65 Reads.

Irvine, Judith T.(1992: ). "Ideologies of Honorific Language". Pragmatics Quarterly Publican of the (IPrA) Home > Vol . 2 No 3 (1992) . International Pragmatics Association.

Levinson,S.C.(1997: 89).Pragmatics. Great Britain, Cambridge University Press.

Lyons, J. (2002:318 -9). Language and Linguistics - An Introduction. U.K., Cambridge University Press.

Matti, Ala'a (2011: 111 -112)."Honorifics in Iraqi Arabic with Special Reference to English: A Sociopragmatic Study". Language, Communication, Information. 1 Kounty, P. Nowak (eds.) 5/2010- 2012:111- 121.

Subova, Marketa (2010:19 -21). Addressing Across Cultures. Magisterska Omova Prace. Filzoficka Fakulta Palacheho v Olomouci.

Takekuro, Makiko (2005:2-3). Attunement in Interaction: Sequential Use of Japanese Honorifics. PhD in Linguistics. University of California, Berkeley.

\section{The Online References}

Htt://en.wikipedia. org/wiki/Honorifics_ Linguistics 
ABOUT THE AUTHOR

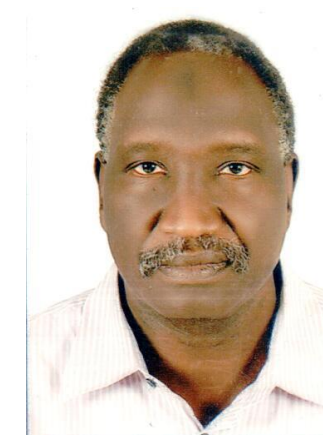

Dr. Abdallah Dawod Omer Jumaa

Assistant Professor,

Applied Linguistics at University of Nyala- Faculty of Education.

Presently working in Department of English Language and Translation,

The College of Science and Arts Unaiza at Al Qassim University-

Kingdom of Saudi Arabia. 